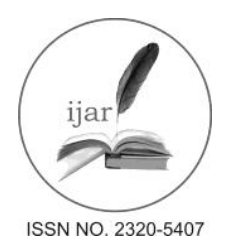

\section{Journal homepage:http://www.journalijar.com \\ Journal DOI:10.21474/IJAR01}

\section{RESEARCH ARTICLE}

INTERNATIONAL JOURNAL

OF ADVANCED RESEARCH

(1)

\title{
ASSESSMENT OF TEMPERATURE AND RAINFALL VARIABILITY ON GRASS PRODUCTIVITY UNDER THREE FOREST RESERVES IN A SAVANNAH ECOSYSTEM IN GHANA.
}

\author{
Ebenezer Djaney Djagbletey ${ }^{1,2}$, S. Adu-Bredu ${ }^{3}$, G. D. Djagbletey ${ }^{3}$, and *H. O. Tuffour ${ }^{1}$. \\ 1. Department of Crop and Soil Sciences, Kwame Nkrumah University of Science and Technology, Kumasi, \\ Ghana. \\ 2. Ghana Forestry Commission, Cape Coast, Ghana. \\ 3. Forestry Research Institute of Ghana, Kumasi, Ghana.
}

\section{Manuscript Info}

Manuscript History:

Received: 16 April 2016

Final Accepted: 26 May 2016

Published Online: June 2016

Key words:

Above-ground biomass,

Below-ground biomass,

Carbon stocks,

Temperature,

Precipitation

*Corresponding Author

H. O. Tuffour.

\section{Abstract}

The study was conducted to determine the grass biomass productivity in three selected forest reserves in the Guinea Savanna agro-ecological zone of Ghana. Prediction of grass productivity using both additive and multiplicative models showed that accuracy in terms of the predictability of the models based on the coefficient of determination (R2) was in the order Klupene (0.816) > Sinsablegbinni (0.664) > Kenikeni (0.660) for the additive model, and Klupene (0.769) > Kenikeni (0.639) > Sinsablegbinni (0.567) for the multiplicative model. It was realised that accuracy in the predictability of the models directly depended on the extent of canopy cover, soil fertility, soil type, wildfires and livestock grazing.

Copy Right, IJAR, 2016.. All rights reserved.

\section{Introduction:-}

Grasslands, which occupy $33 \times 106 \mathrm{~km}^{2}$ are important terrestrial biomes, occupying an area of about, and play an important role in global carbon balance because of their large area and significant sink or source capacities (Nagy et al., 2007). Several studies (e.g. Fisher et al., 2007; Fidelis et al., 2013; Toma et al., 2013) have been conducted on the carbon stocks in different grasslands of the world. From the studies by Long et al. (1992)on grasslands in Kenya, Mexico and Thailand, accumulation of $144 \mathrm{~g} \mathrm{C} / \mathrm{m}^{2} / \mathrm{yr}$ was observed when protected from fires. As a result, they concluded that these grasslands were potentially significant C sinks. On the other hand, Fisher et al. (1994; 1995)found that the introduction of African grasses into the savannas of South America increased soil organic matter and accumulated more $\mathrm{C}$ in soil than native grasses, which implies their greater potential in $\mathrm{C}$ storage. In Ghana, grasslands have originated from forest ecosystems as a result of deforestation and abandoned agricultural systems and are maintained at various succession levels by grazing, burning and harvesting. However, information on the biomass and productivity as well as carbon storage in the grasslands are not available.

\section{Material and Methods:-}

Description of study areas:-

The study was carried out at the Kenikeni, Sinsablegbinni and Klupene forest reserves in the Guinea Savanna Agroecological Zone of Ghana. The Kenikeni site is located in the Bole forest District (Bole District), while the Sinsablegbinni forest reserve is in the Tamale forest District (Tamale Metropolis). The Klupene forest reserve is in the Yendi forest District (Yendi Municipality). All the three forest reserves are in the Northern Region of Ghana. 


\section{Assessment of grass carbon stock:-}

The weight of all the grasses were determined in each of five one squared metre $(1.0 \mathrm{~m} \mathrm{x} 1.0 \mathrm{~m})$ randomly laid quadrats (in the $25 \mathrm{~m} \times 25 \mathrm{~m}$ sub-plots). For one year (12 calendar months), all growing grasses in each of the $1.0 \mathrm{~m}$ x 1.0 mquadrats were cut monthly to the ground level with secateurs, and the fresh weights determined in the field using a digital weighing balance. Fresh sub-samples for each $1.0 \mathrm{~m} \times 1.0 \mathrm{~m}$ were re-weighed, placed in labelled envelopes and taken to the laboratory to determine the oven dry weight at $75^{\circ} \mathrm{C}$ until constant weight (Djagbletey, 2015). At the end of the twelfth month, the fresh grass vegetation within each quadrat was carefully uprooted by digging with the chisel to $100 \mathrm{~cm}$ depth to ensure that all the roots were intact. Each grass root was freed of all stones and sand particles. Shoots were severed from roots with a pair of scissors and each was freshly weighed with the digital weighing balance on the field.

The grass vegetation in the five $1 \mathrm{~m} \times 1 \mathrm{~m}$ quadrats were collected and their fresh mass weighed in the field, using digital weighing scale. Samples were taken for oven drying at $75^{\circ} \mathrm{C}$ to constant mass (Djagbletey, 2015). The dry mass of the samples were calculated as:

Where $\left(\mathrm{Mg} \mathrm{ha}^{-1}\right)$ is the non-tree (i.e., grass) biomass, $(\mathrm{g})$ is sample dry mass, $(\mathrm{g})$ is sample fresh mass, $(\mathrm{Mg})$ is total fresh mass of grass in the quadrat and $A\left(\mathrm{~m}^{2}\right)$ is the size of the quadrat. The carbon content value given by AduBredu et al. (2010) as 0.3746 was used to convert the tree, non-tree (grass) biomass to the corresponding carbon biomass. The SAS System for windows 9.0 was utilized in fitting non-linear regression models (both additive and multiplicative) for the grass productivity.

\section{Result and Discussion:-}

Figure 1a shows that the average carbon stocks of the above-ground biomass (AGB) of grass were $0.291 \mathrm{Mg} \mathrm{C}^{-1}$, $0.136 \mathrm{Mg} \mathrm{C}^{-1}$ and $0.090 \mathrm{Mg} \mathrm{C} \mathrm{ha}^{-1}$ for Klupene, Sinsablegbinni and Kenikeni forest reserves, respectively. On the other hand, the high carbon stock obtained for the below ground biomass of grass was in the order of Kenikeni forest reserve $\left(0.444 \mathrm{Mg} \mathrm{C}^{-1}\right)>$ Sinsablegbinni forest reserve $\left(0.066 \mathrm{Mg} \mathrm{C}^{-1}\right)>$ Klupene forest reserve $(0.025 \mathrm{Mg} \mathrm{C}$ $\left.\mathrm{ha}^{-1}\right)$ (Figure 1b).

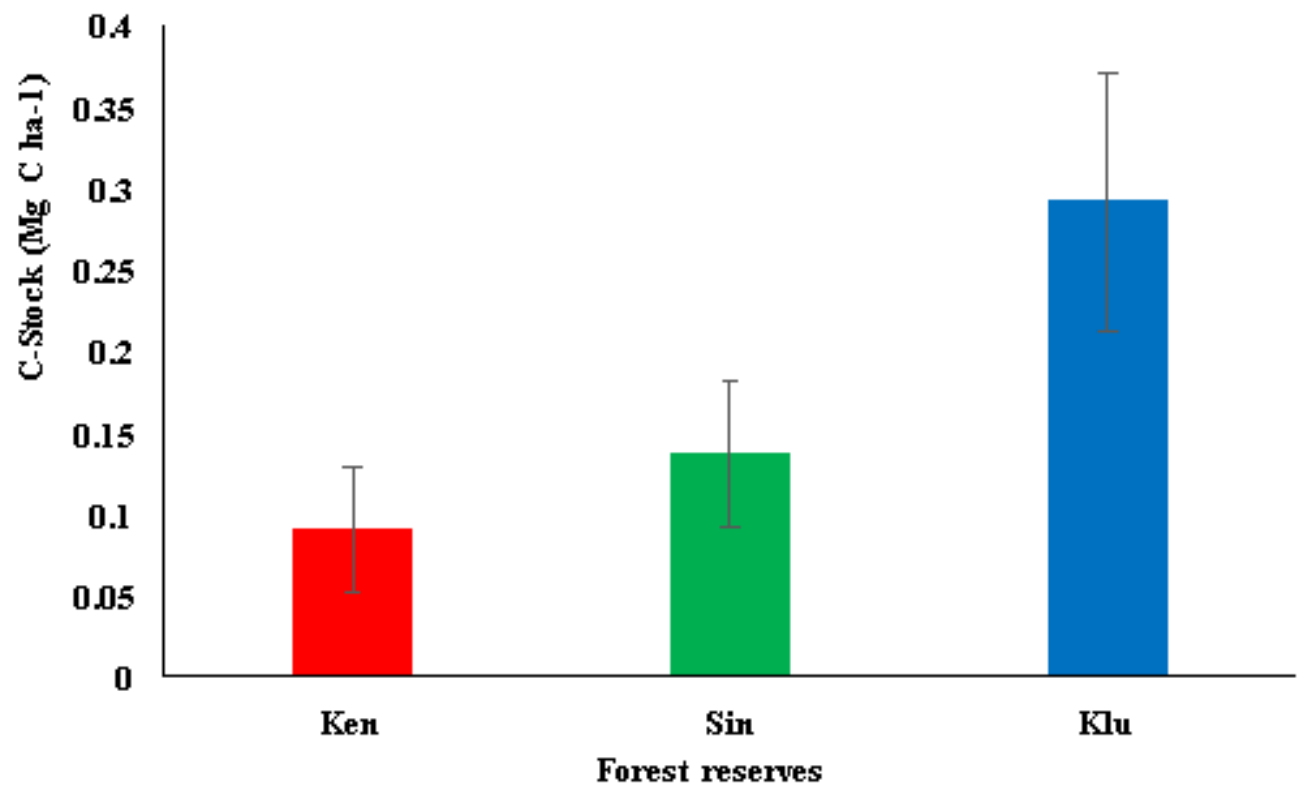

Figure 1a:-Aboveground Grass Carbon Stock $\left(\mathrm{Mg} \mathrm{C} \mathrm{ha}^{-1}\right)$ in the three forest reserves. 


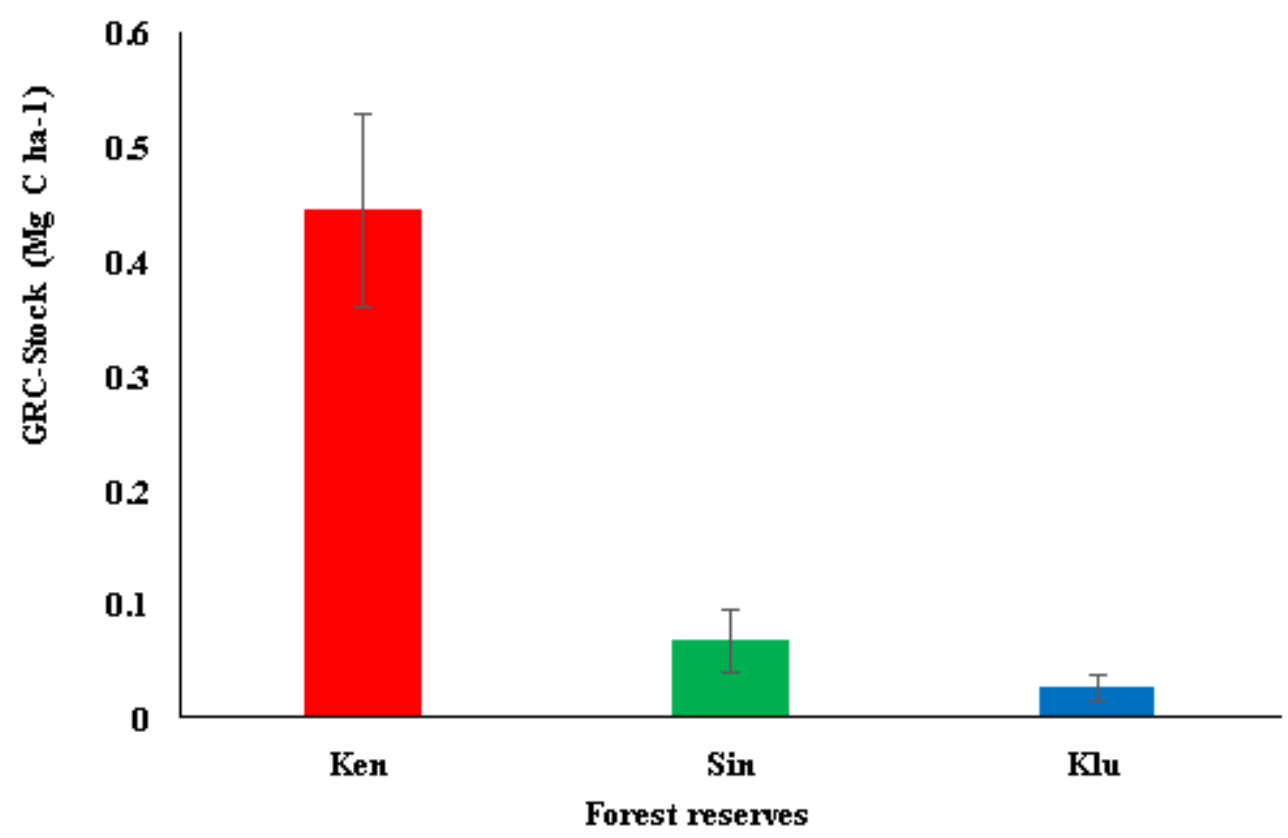

Figure 1b:-Belowground Grass Carbon Stock $\left(\mathrm{Mg} \mathrm{C} \mathrm{ha}^{-1}\right)$ in the three forest reserves.

The effect of seasonality on the overall grass $\mathrm{C}$ stock in the three forest reserves is shown in Figure 2. Generally, the results from the study showed that the total grass $\mathrm{C}$ stock in the three forest reserves was highest in the wettest periods (i.e. June-July) and declined in the driest periods (November-March) of the year.

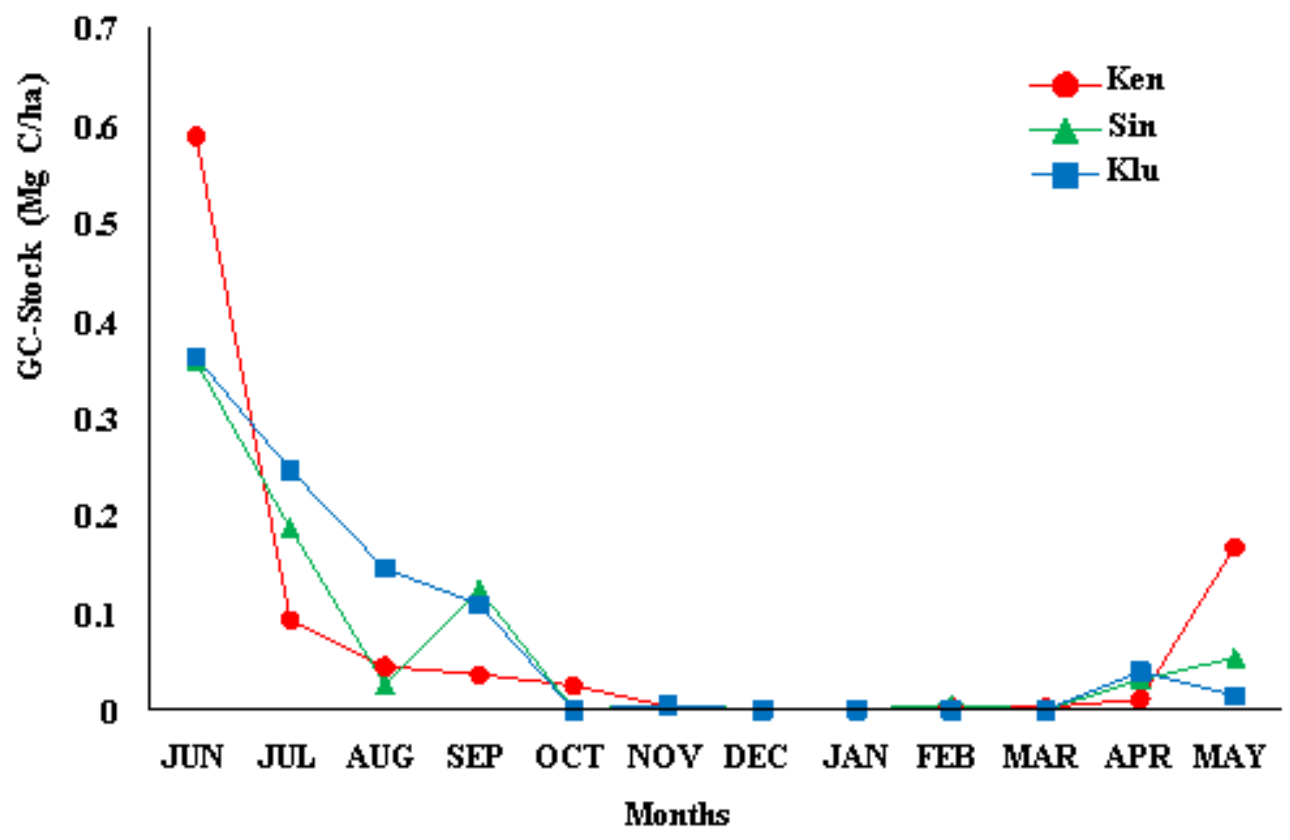

Figure 2:-Trend of Grass Productivity in the three forest reserves.

Effects of periodic rainfall variations on grass productivity:-

Impacts of monthly variations in precipitation on grass productivity in the different forest stands are presented in Figures $3 a-c$, wherein grass productivity was correlated roughly with monthly rainfall. 


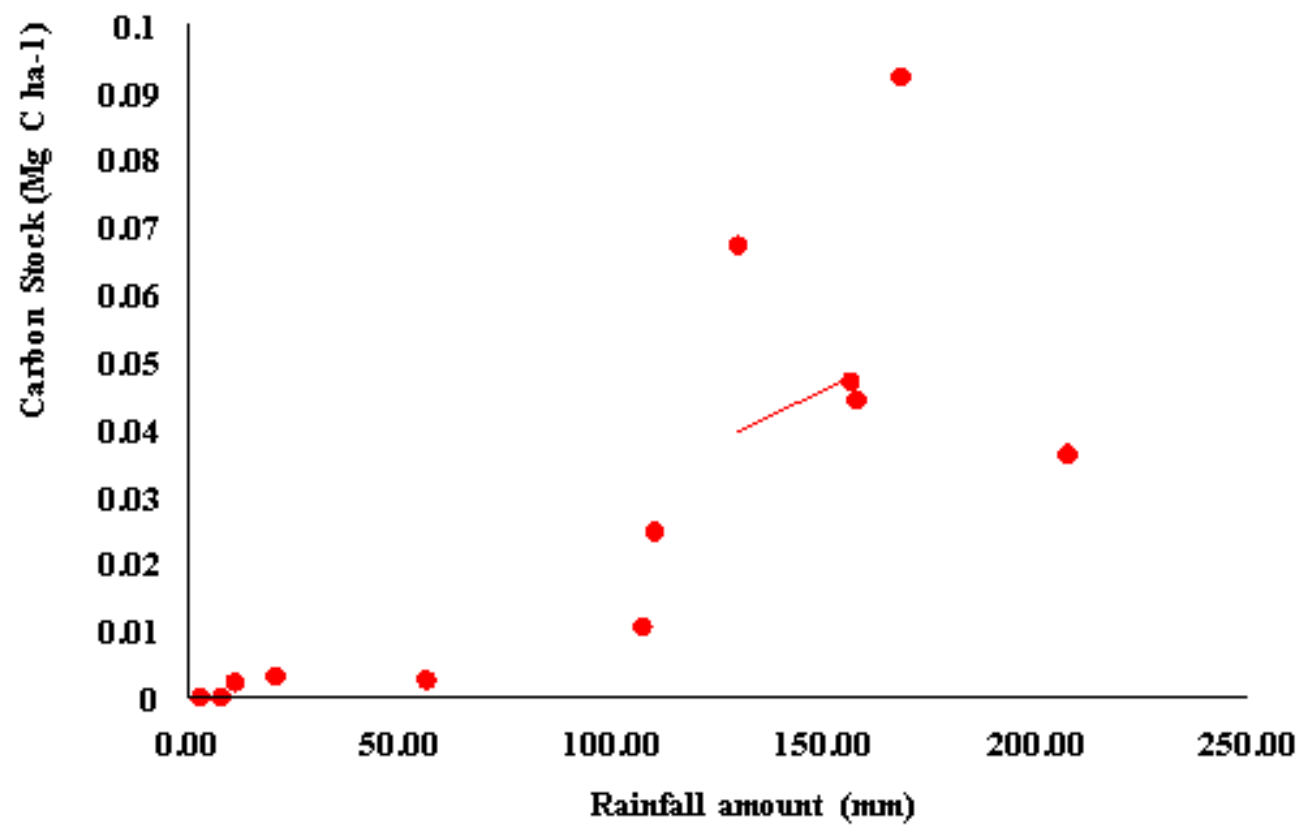

Figure 3a:-Rainfall amount and Grass productivity in Kenikeni Forest Reserve.

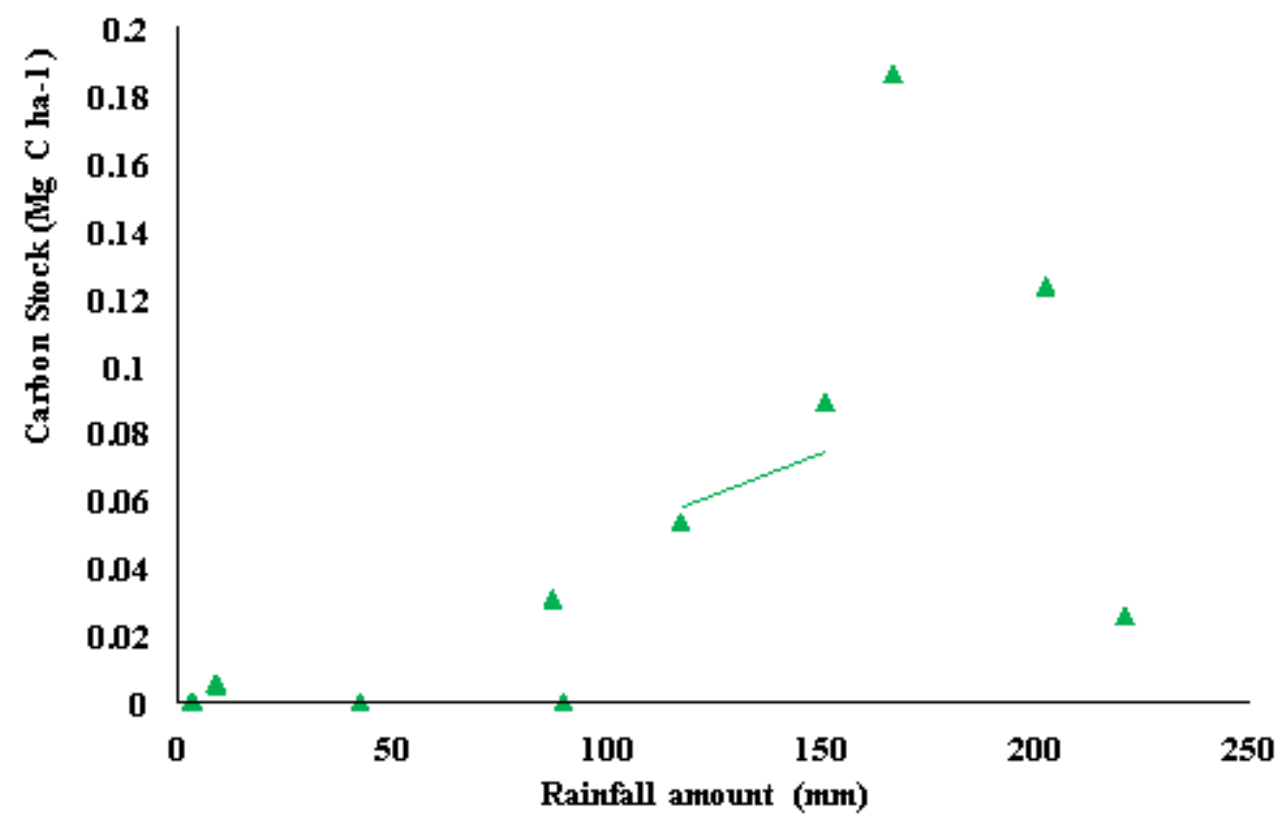

Figure 3b:-Rainfall amount and Grass productivity in Sinsablegbinni Forest Reserve. 


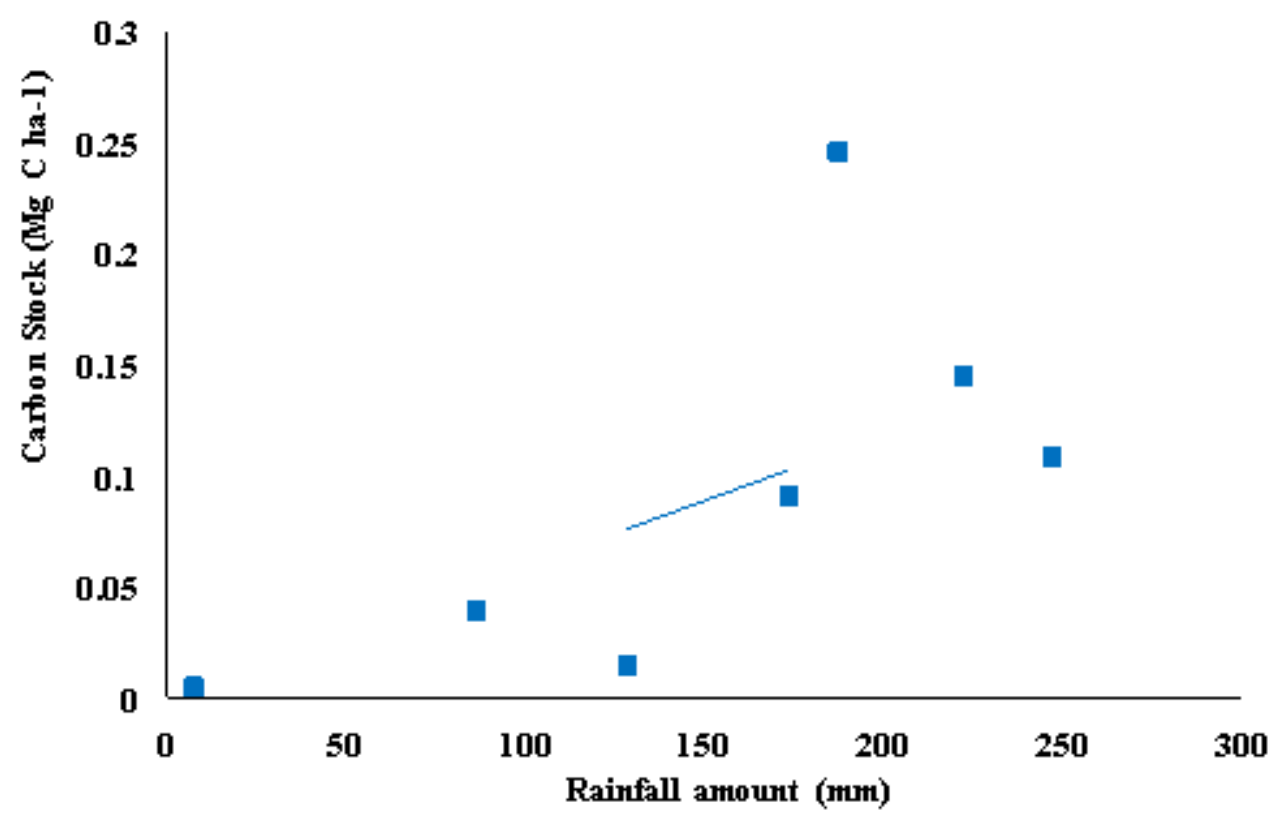

Figure 3c: - Rainfall amount and Grass productivity in Klupene Forest Reserve.

The results clearly show that the monthly variations in rainfall amount in the different forest stands had significant impacts on the changes in grass productivity, indicating that the response of grass productivity depended on which periods received extra water and which periods received less water. The results of the presented study exhibited a similar trend across the three forest types, with a positive correlation between rainfall amount and grass productivity. However, the goodness-of-fit of the regression model (Figures $3 \mathrm{a}-\mathrm{c}$ ) as reflected by the range of the coefficients of determination $\left(\mathrm{R}^{2}\right)(0.472-0.607)$ was poor for all three forest stands. This indicates that the prediction model with its underlying principles and assumptions were overly simplified. Nonetheless, the models have improved the ability to account for annual grass productivity in spite of the inconsistencies in respect of the ecosystem types. This implies that the results extend further than site-specificity (Suttle et al., 2007), and reveals the generalization and strength of the effects of periodic variations in rainfall on annual grass productivity in different forest stands.

From similar studies on seasonal variations in rainfall conducted in arctic tundra (Schimel et al., 2004), boreal forests (Gaul et al., 2008), tropical rainforests in the Amazon (Nepstad et al., 2002; Brando et al., 2006; 2008), Mediterranean regions, such as Spain (Miranda et al., 2009) and oak savannas (Volder et al., 2010; 2013), marked variations were observed to exist among grasslands, savannas and Mediterranean forests with regards to the occurrence of ambient precipitation and the length of the growing season. However, according to Zeppel et al. (2014), similar patterns exist in responses to periodic changes in precipitation, for example changes in water stress and productivity in warm or dry seasons and not in cool or wet periods. The various forest stands ranging from intact (Kenikeni) to degraded (Klupene) forests were all most sensitive to rainfall distribution during at least one period of the year. It was expected that the intact forest stand would respond differently than the other forest types, with higher average rainfall to prevent the occurrence of water deficit that could affect grass productivity. Conversely, the progress from using periodic rainfall amount was similar across all forest stands and there was no specific period that was more closely associated with one forest type over another. Notwithstanding the exact mechanism, the results clearly indicate that variations in the distribution of rainfall during the growing season will ultimately affect grass productivity in different forest stands.

Contrary to the suggestions by previous studies (e.g. Webb et al., 1978; 1983; Knapp and Smith, 2001), wherein grassland production varied highly with variation in precipitation across years, the results from this study has shown that different ecosystems are sensitive to the distribution of precipitation within the growing season. For instance, Morecroft et al. (2004) observed that a $20 \%$ increase in summer precipitation increased summer growth, whereas increased autumn and winter precipitation had no effect on growth in a limestone grassland in England. This implies that reductions in rainfall are only likely to influence plant processes if soil moisture is limiting in the season (Zeppel et al., 2014). Furthermore, the periodic variations in rainfall does not only affect water stress and biomass, 
but phenological characteristics such as flowering of male and female plants (Misson et al., 2011) and tiller production (Volder et al., 2013). In summary, changes in rainfall amount towards the wetter periods had a more dramatic impact on vegetation than in the drier periods reflecting larger effects of redistributed rainfall on grass productivity in all three forest stands.

\section{Effects of periodic temperature variations on grass productivity}

A general observation made across the three study areas was that temperature elevations reduced grass productivity over the sampling period (Figures $4 \mathrm{a}-\mathrm{c}$ ).

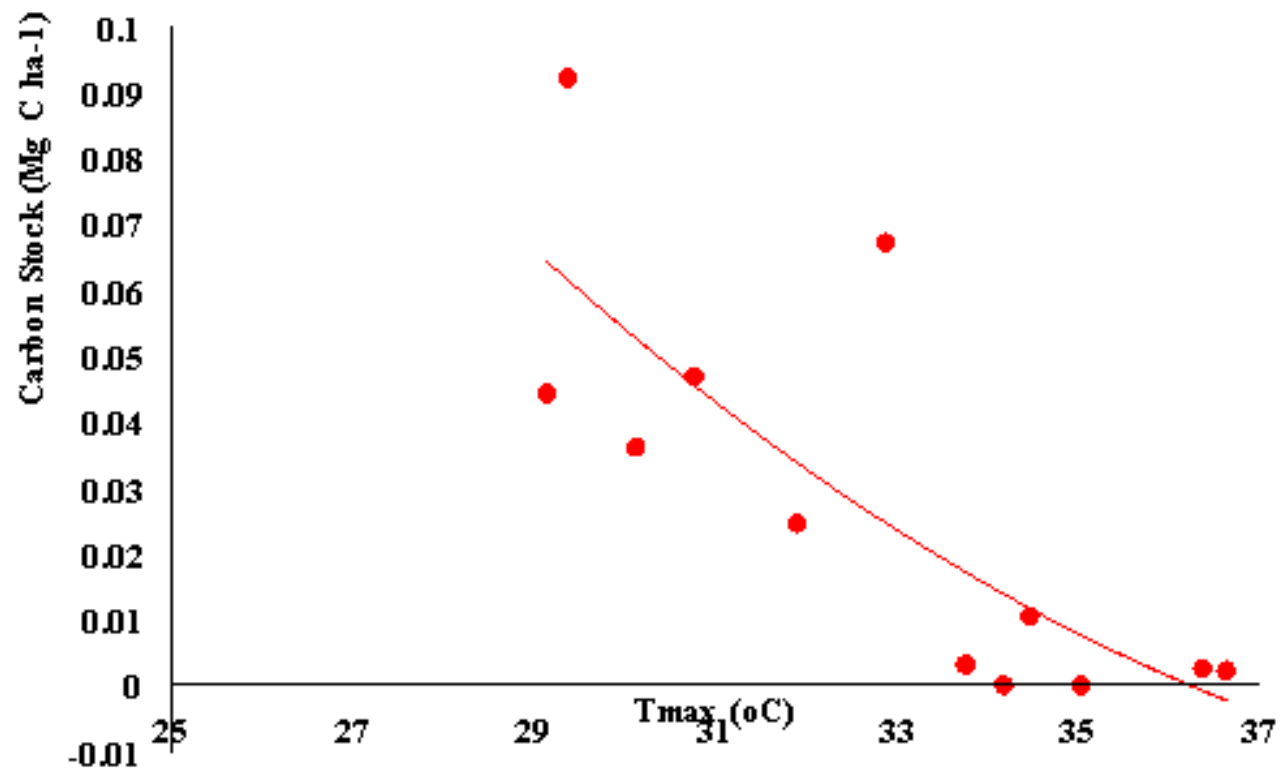

Figure 4a:-Maximum Temperature $\left({ }^{\circ} \mathrm{C}\right)$ and Grass productivity in Kenikeni Forest Reserve.

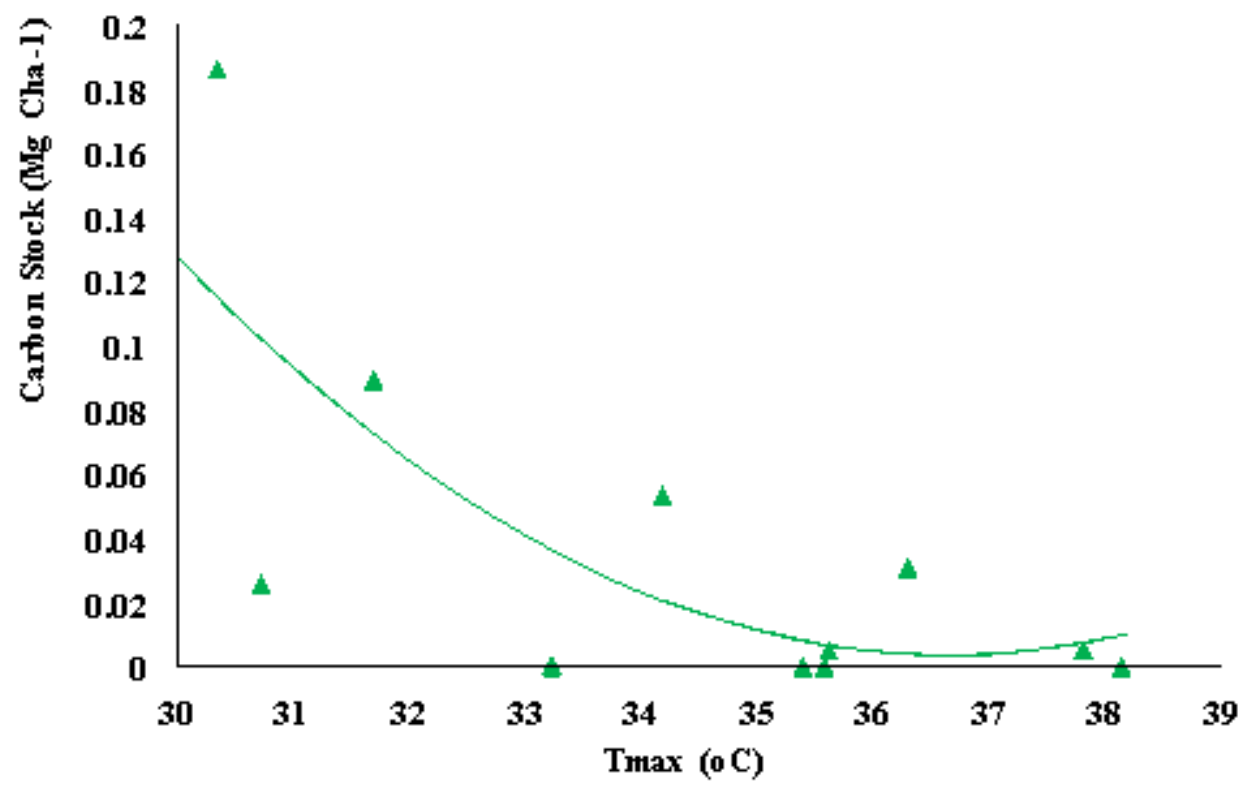

Figure 4b:- Maximum Temperature $\left({ }^{\circ} \mathrm{C}\right)$ and Grass productivity in Sinsablegbinni Forest Reserve. 


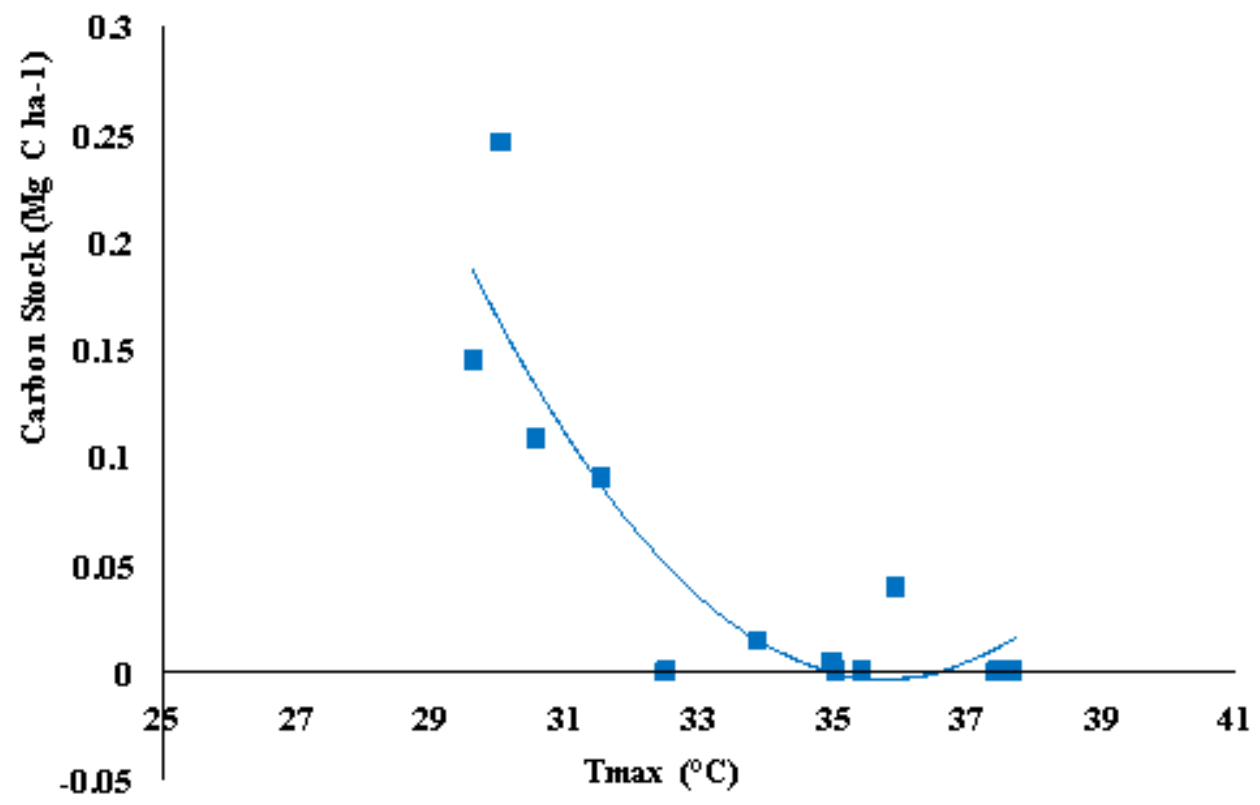

Figure 4c:-Maximum Temperature $\left({ }^{\circ} \mathrm{C}\right)$ and Grass productivity in Klupene Forest Reserve.

Typically, the response to temperature during the season was greatest when the soils were wettest, but not driest. Thus, high temperatures arising from intense heat waves reduced grass productivity in all three study sites, indicating a negative correlation between temperature and grass productivity. Similarly, Craine et al. (2012)observed that a $1^{\circ} \mathrm{C}$ rise in mean daily maximum temperature resulted in a reduction of $19.6 \pm 8.3 \mathrm{~g} / \mathrm{m}^{2}$ in grass productivity. While the impact of drought in reducing grass productivity can be explained by decreased water availability, which limits photosynthesis (Knapp, 1985), temperature elevations arising from extreme heat waves also reduced grass productivity by reducing soil moisture through increased evapotranspiration (Reichstein et al., 2007; Amone et al., 2008; De Boek et al., 2011). Thus, with full concentration on the indirect effects of temperature on water balance explains a common mechanism that explains the effects of rainfall distribution (Figures $3 a-c$ ) and temperature variations (Figures $4 \mathrm{a}-\mathrm{c}$ ) (Craine et al., 2012). Other mechanisms such as the possibility that high temperatures associated with intense heat waves could generate physiological stress directly cannot be excluded (Crafts-Brandner and Salvucci, 2002; Craine et al., 2012).

Additionally, the peak temperatures from all three forest stands were generally below the optimum temperatures reported for photosynthesis for $\mathrm{C} 4$ grasses, and increases in peak air temperature that were well below optimum photosynthetic temperatures were associated with lower productivity (Sage and Kubien, 2007; Kakani et al., 2008; Craine et al., 2012). The highest air temperature observed across the three sites were well below $42^{\circ} \mathrm{C}$ during the study period, although leaf temperatures can often be higher than air temperatures (Knapp, 1984; Helliker and Richter, 2008; Craine et al., 2012). Moreover, elevated temperatures could also have impacted negatively on the mineralization of soil N (Dessureault-Rompré et al., 2010), and also enhanced the feeding rate of grasshoppers (Lactin and Johnson, 1995; Chase, 1996), thereby generating a lower grass productivity (Craine et al., 2012).

\section{Prediction of grass productivity:-}

Prediction of grass productivity using both additive and multiplicative models is summarized in Table 1. The modelling process was performed to estimate the effects of rainfall, maximum temperature and soil chemical properties in the three different sites on grass productivity. The predictive models describing both additivity and multiplicativity in the various forest stands are presented in equations 1 and 2, respectively, with their empirical constants presented in Tables 1 and 2.

where,

Grass productivity $\left(\mathrm{Mg} \mathrm{Cha}^{-1}\right)$

, , and are site-specific empirical constants with no physical meaning

Rainfall amount (mm)

Maximum temperature $\left({ }^{\circ} \mathrm{C}\right)$ 
Table 1:-Summary of grass productivity modeling.

\begin{tabular}{|c|c|c|c|}
\hline \multirow[t]{2}{*}{ Site } & \multirow[t]{2}{*}{ Model } & \multicolumn{2}{|c|}{ Prediction index } \\
\hline & & $\mathbf{R}^{2}$ & RMSE \\
\hline Kenikeni & \multirow{3}{*}{ Additive } & 0.660099 & 0.016934 \\
\hline Sinsablegbinni & & 0.664374 & 0.034634 \\
\hline \multirow[t]{2}{*}{ Klupene } & & 0.815606 & 0.034272 \\
\hline & Pooled & 0.555683 & 0.038853 \\
\hline Kenikeni & \multirow[t]{3}{*}{ Multiplicative } & 0.639064 & 0.017451 \\
\hline Sinsablegbinni & & 0.567145 & 0.040475 \\
\hline \multirow[t]{2}{*}{ Klupene } & & 0.769889 & 0.039966 \\
\hline & Pooled & 0.559701 & 0.038678 \\
\hline
\end{tabular}

$\mathrm{R}^{2}=$ Coefficient of determination; RMSE $=$ Root mean square error

The result of the slopes of the regression forced through the origin showed that the model satisfactorily predicted grass productivity based on additivity than multiplicativity. This is evidenced by the high values of the coefficient of determination $\left(\mathrm{R}^{2}\right)$ ranging from $0.660099-0.815606$, and low RMSE values which lay between 0.016934 and 0.034634 . Thus, the prediction indices clearly showed that the additive model satisfactorily predicted the grass productivity, especially in the Klupene forest than the Kenikeni and Sinsablegbinni. Additionally, from the prediction indices (i.e., $\mathrm{R}^{2}$ and RMSE), the accuracy of prediction of grass productivity was in the order Klupene > Sinsablegbinni > Kenikeni under the additive effect, and Klupene > Kenikeni > Sinsablegbinni under the multiplicative effect. However, the fit of the model (based on the RMSE and $\mathrm{R}^{2}$ ) was significantly reduced when individually, the additive and multiplicative models for the various sites were pooled (Table 2).

Table 2:-Model parameters and predictive indices for grass productivity for the different forest reserves.

\begin{tabular}{|c|c|c|c|c|c|c|c|}
\hline \multirow[t]{2}{*}{ Site } & \multirow[t]{2}{*}{ Model } & \multicolumn{4}{|c|}{ Model parameters } & \multicolumn{2}{|c|}{ Predictive index } \\
\hline & & & & & & $\mathbf{R}^{2}$ & RMSE \\
\hline Kenikeni & \multirow[t]{3}{*}{ Additive } & 0.000182 & 0.000268 & 0.0223 & 0.4513 & 0.660099 & 0.016934 \\
\hline Sinsablegbinni & & -0.00010 & 0.00311 & 0.2287 & 4.2136 & 0.664374 & 0.034634 \\
\hline \multirow[t]{2}{*}{ Klupene } & & -0.00007 & 0.00529 & 0.3792 & 6.7950 & 0.815606 & 0.034272 \\
\hline & Pooled & 0.000277 & 0.00155 & 0.1119 & 2.0098 & 0.555683 & 0.038853 \\
\hline Kenikeni & \multirow[t]{3}{*}{ Multiplicative } & 0.000794 & -0.00413 & -0.2328 & -2.8551 & 0.639064 & 0.017451 \\
\hline Sinsablegbinni & & 0.00538 & 0.00290 & 0.2022 & 3.5685 & 0.567145 & 0.040475 \\
\hline \multirow[t]{2}{*}{ Klupene } & & 0.00947 & 0.00291 & 0.2022 & 3.5291 & 0.769889 & 0.039966 \\
\hline & Pooled & 0.00257 & 0.00272 & 0.2022 & 3.8335 & 0.559701 & .038678 \\
\hline
\end{tabular}

The decrease in the goodness-of-fit of the model after pooling the effects may be attributable to differences in canopy closure, which may have effect on incident solar radiation on the forest floor to facilitate photosynthesis to enhance grass growth. Furthermore, other factors such as soil fertility, soil type, wildfire and livestock grazing may have contributed to the poor predictability under the pooled effect. According to Tuffour and Bonsu (2015), the relationship between $\mathrm{R}^{2}$ and RMSE does not follow a definite pattern, which implies that a higher $\mathrm{R}^{2}$ value did not always correspond to a lower RMSE. For example, under the additive effect, Klupene recorded $\mathrm{R}^{2}$ value of 0.815606 with high RMSE of 0.034272 , while Kenikeni, which recorded the lowest $\mathrm{R}^{2}$ value of 0.660099 had the lowest RMSE value of 0.016934. Holistically, the collective analyses of the entire data on grass productivity showed that the model satisfactorily predicted under both additive and multiplicative for the Klupene forest reserve.

Overall, the results showed that grass $\mathrm{C}$ stocks differed significantly between above- and below-ground biomass among the various sites. Overall, the contribution of above ground biomass to total carbon stock of grass was higher than that of below ground biomass. Furthermore, as presented in Figures 1a and b, accumulation of carbon in the above ground biomass increased with forest degradation, whereas that of the below ground biomass increased with increased vegetation cover. Thus, root $\mathrm{C}$ stock was significantly high due to the absence of forest degradation at Kenikeni. This implies that, in the absence of forest degradation, the shading effects of the tree canopies resulting in reduced photosynthetic activities of the grasses may have resulted in the investment of $\mathrm{C}$ in the below-ground biomass (i.e., roots) of the grasses other than the above-ground biomass. On the other hand, reduction in tree canopy 
levels resulting from forest degradation might have resulted in the stocking of $\mathrm{C}$ in the above-ground biomass, due to an increase in the amount of solar radiation with a concomitant intensification in photosynthesis in these opencanopy environments. These observations are evidenced by the below- to above-ground biomass ratio, which was significantly higher in the Kenikeni forest (4.93) than in the Sinsablegbinni forest (0.48) and Klupene forest (0.087), respectively. The fact that most other studies on biomass have been conducted in a range of high-altitude tropical and temperate grasslands (Hofstede et al., 1995) coupled with different sampling techniques make comparisons difficult (Hafner et al., 2012). As a result, (Hafner et al., 2012) have recommended the use of a more standardized methodology to enhance the assessments across multiple locations. This will create a better understanding of the spatial distribution of carbon content different ecosystems. Another source of variation among studies is seasonality and time of biomass sampling (Hafner et al., 2012). In this study, seasonal effects were considered, since seasonality in the study area is highly significant, because precipitation, radiation and temperature are highly variable throughout the year.

\section{Conclusions:-}

From the study, Klupene forest recorded the highest carbon stock in the above ground biomass, whereas, for the below ground biomass, Kenikeni recorded the highest. Thus, accumulation of carbon in the above ground biomass increased with increasing forest degradation, whereas that of the below ground biomass increased with increasing vegetation cover. These observations clearly show the effects of canopy cover on solar radiation reception, and eventually, photosynthetic activities under forest stands. Additionally, monthly variations in both rainfall and temperature were found to significantly alter grass productivity in the different stands. Thus, changes in rainfall amount towards the wetter periods had a more dramatic impact on grass production than in the drier periods in all three forest stands. Prediction of grass productivity using both additive and multiplicative models showed that accuracy in terms of the predictability of the models was in the order Klupene > Sinsablegbinni > Kenikeni for the additive model, and Klupene > Kenikeni > Sinsablegbinni for the multiplicative model. Overall, it was noted that the accurate prediction by the models was directly related to canopy cover, soil fertility, soil type, wildfires and livestock grazing.

\section{References:-}

1. Adu-Bredu, S., Abekoe, M.K., Tachie-Obeng, E. and Tschakert, P. (2010). Carbon stock under four landuse systems in three varied ecological zones in Ghana. In: Bombelli, A. and Valentini, R. (eds). Africa and the carbon cycle: proceedings of the Open Science Conference on Africa and the Carbon Cycle: the CarboAfrica Project. Accra (Ghana) 25-27 November 2008. FAO World Soil Resources Report. 10: 105-113pp.

2. Arnone, J.A., Verburg, P.S., Johnson, D.W., Larsen, J.D., Jasoni, R.L., Lucchesi, A.J. and Buck, P.E. (2008). Prolonged suppression of ecosystem carbon dioxide uptake after an anomalously warm year. Nat. 455(7211): 383-386.

3. Brando, P., Ray, D., Nepstad, D., Cardinot, G., Curran, L.M. and Oliveira, R. (2006). Effects of partial throughfall exclusion on the phenology of Coussarea racemosa (Rubiaceae) in an east-central Amazon rainforest. Oecologia. 150(2): 181-189.

4. Brando, P.M., Nepstad, D.C., Davidson, E.A., Trumbore, S.E., Ray, D. and Camargo, P. (2008). Drought effects on litterfall, wood production and belowground carbon cycling in an Amazon forest: results of a throughfall reduction experiment. Philosophical Transactions of the Royal Society of London B: Bio. Sci. 363(1498): 1839-1848.

5. Chase, J.M. (1996). Abiotic controls of trophic cascades in a simple grassland food chain. Oikos. $495-506$.

6. Crafts-Brandner, S.J. and Salvucci, M.E. (2002). Sensitivity of photosynthesis in a C4 plant, maize, to heat stress. Plant Phy. 129: 1773-1780.

7. Craine, J.M., Nippert, J.B., Elmore, A.J., Skibbe, A.M., Hutchinson, S.L. and Brunsell, N.A. (2012). Timing of climate variability and grassland productivity. Proc. Nat. Acad. Sci. 109(9): 3401-3405.

8. De Boeck, H.J., Dreesen, F.E., Janssens, I.A. and Nijs, I. (2011). Whole-system responses of experimental plant communities to climate extremes imposed in different seasons. New Phyt. 189(3): 806-817.

9. Dessureault-Rompré J., Zebarth, B.J., Georgallas, A., Burton, D.L., Grant, C.A. and Drury, C.F. (2010). Temperature dependence of soil nitrogen mineralization rate: Comparison of mathematical models, reference temperatures and origin of the soils. Geoderma. 157(3): 97-108.

10. Djagbletey, G.D. (2015). Impact of Selective Logging on Plant diversity, Natural Recovery and Vegetation Carbon Stock: The case of Bobiri forest reserve. PhD. Thesis. College of Agriculture and Natural Resources (CANR), Kwame Nkrumah University of Science and Technology (KNUST), Kumasi-Ghana. 
11. Fidelis, A., Lyra, M.F.S. and Pivello, V.R. (2013). Above- and below-ground biomass and carbon dynamics in Brazilian Cerrado wet grasslands. J. Veg. Sci. 24: 356-364.

12. Fisher, M.J., Braz, S.P., dos Santos, R.S.M., Urquiaga, S., Alves, B.J.R. and Boddey, R.M. (2007). Another dimension to grazing systems: Soil carbon. Trop. Grass. 41: 65-83.

13. Fisher, M.J., Lascano, C.E., Rao, I.M., Sanz, J.I., Thomas, R.J., Vera, R.R. and Ayarza, M.A. (1995). Pasture soils as carbon sink. Nat. 376(6540): 376: 473.

14. Fisher, M.J., Rao, I.M., Ayarza, M.A., Lascano, C.E., Sanz, J.I., Thomas, R.J. and Vera, R.R. (1994). Carbon storage by introduced deep-rooted grasses in the South American savannas. Nat. 371: 236-238.

15. Gaul, D., Hertel, D. and Leuschner, C. (2008). Effects of experimental soil frost on the fine-root system of mature Norway spruce. J. Plant Nut. Soil Sci. 171(5): 690-698.

16. Hafner, S., Unteregelsbacher, S., Seeber, E., Lena, B., Xu, X., Li, X. and Kuzyakov, Y. (2012). Effect of grazing on carbon stocks and assimilate partitioning in a Tibetan montane pasture revealed by $13 \mathrm{CO}_{2}$ pulse labeling. Global Change Bio. 18(2): 528-538.

17. Helliker, B.R. and Richter, S.L. (2008). Subtropical to boreal convergence of tree-leaf temperatures. Nature. 454: 511-514.

18. Hofstede, R.G., Castillo, M.X.M. and Osorio, C.M.R. (1995). Biomass of grazed, burned, and undisturbed páramo grasslands, Colombia. I. Aboveground vegetation. Arc. Alp. Res. 1-12.

19. Kakani, V.G., Surabhi, G.K. and Reddy, K.R. (2008). Photosynthesis and fluorescence responses of C4 plant Andropogon gerardii acclimated to temperature and carbon dioxide. Photosynthetica. 46: 420-430.

20. Knapp, A.K. (1985). Effect of fire and drought on the ecophysiology of Andropogon gerardii and Panicum virgatum in a tallgrass prairie. Ecol. 66:1309-1320.

21. Knapp, A.K. and Smith, M.D. (2001). Variation among biomes in temporal dynamics of aboveground primary production. Sci. 291(5503): 481-484.

22. Lactin, D.J. and Johnson, D.J. (1995). Temperature-dependent feeding rates of Melanoplus sanguinipes nymphs (Orthoptera: Acrididae) in laboratory trials. Environ. Ento. 24(5): 1291-1296.

23. Long, S.P., Jones, M.B. and Roberts, M.J. (1992). Primary productivity of grass ecosystems of the tropics and subtropics. Chapman and Hall, New York, USA.

24. Miranda, J.D.D., Padilla, F.M., Lázaro, R. and Pugnaire, F.I. (2009). Do changes in rainfall patterns affect semiarid annual plant communities? J. Veg. Sci. 20(2): 269-276.

25. Misson, L., Degueldre, D., Collin, C., Rodriguez, R., Rocheteau, A., Ourcival, J. and Rambal, S. (2011). Phenological responses to extreme droughts in a Mediterranean forest. Global Change Bio. 17(2): 1036-1048.

26. Morecroft, M.D., Masters, G.J., Brown, V.K., Clarke, I.P., Taylor, M.E. and Whitehouse, A.T. (2004). Changing precipitation patterns alter plant community dynamics and succession in an ex-arable grassland. Fun. Ecol. 18(5): 648-655.

27. Nagy, Z., Pintér, K., Czóbel, Sz., Balogh, J., Horváth, L., Fóti, Sz., Barcza, Z., Weidinger, T., Csistalan, Z., Dinh, N.Q., Grosz, B. and Tuba, Z. (2007). The carbon budget of semi-arid grassland in a wet and a dry year in Hungary. Agric. Eco. Environ. 121: 21-29.

28. Nepstad, D., Lefebvre, P., Lopes da Silva, U., Tomasella, J., Schlesinger, P., Solorzano, L. and Guerreira Benito, J. (2004). Amazon drought and its implications for forest flammability and tree growth: A basin-wide analysis. Global Change Bio. 10(5): 704-717.

29. Reichstein, M., Ciais, P., Papale, D., Valentini, R., Running, S., Viovy, N. and Aubinet, M. (2007). Reduction of ecosystem productivity and respiration during the European summer 2003 climate anomaly: a joint flux tower, remote sensing and modelling analysis. Global Change Bio. 13(3): 634-651.

30. Sage, R.F. and Kubien, D.S. (2007). The temperature response of C3 and C4 photosynthesis. Plant, Cell Environ. 30(9): 1086-1106.

31. Schimel, J.P., Bilbrough, C. and Welker, J.M. (2004). Increased snow depth affects microbial activity and nitrogen mineralization in two Arctic tundra communities. Soil Bio. Biochem. 36(2): 217-227.

32. Suttle, K.B., Thomsen, M.A. and Power, M.E. (2007). Species interactions reverse grassland responses to changing climate. Sci. 315(5812): 640-642.

33. Toma, Y., Cliffton-Brown, J., Sugiyama, S., Nakaboh, M., Hatano, R., Fernández, F.G., Stewart, J.R., Nishiwaki, A. and Yamada, T. (2013). Soil carbon stocks and carbon sequestration rates in seminatural grassland in Aso region, Kumamoto, Southern Japan. Global Change Bio. 19(6): 1676-1687.

34. Tuffour, H.O. and Bonsu, M. (2015). Application of Green and Ampt Equation to infiltration with soil particle phase. Int. J. Sci. Res. Agric. Sci. 2(4): 76-88. 
35. Volder, A., Briske, D.D. and Tjoelker, M.G. (2013). Climate warming and precipitation redistribution modify tree-grass interactions and tree species establishment in a warm-temperate savanna. Global Change Bio. 19(3): 843-857.

36. Volder, A., Tjoelker, M.G. and Briske, D.D. (2010). Contrasting physiological responsiveness of establishing trees and a C4 grass to rainfall events, intensified summer drought, and warming in oak savanna. Global Change Bio. 16(12): 3349-3362.

37. Webb, W., Szarek, S., Lauenroth, W., Kinerson, R. and Smith, M. (1978). Primary productivity and water use in native forest, grassland, and desert ecosystems. Ecol. 59(6): 1239-1247.

38. Webb, W.L., Lauenroth, W.K., Szarek, S.R. and Kinerson, R.S. (1983). Primary production and abiotic controls in forests, grasslands, and desert ecosystems in the United States. Ecol. 134-151.

39. Zeppel, M.J.B., Wilks, J.V. and Lewis, J.D. (2014). Impacts of extreme precipitation and seasonal changes in precipitation on plants. Biogeosci. 11(11): 3083-3093. 